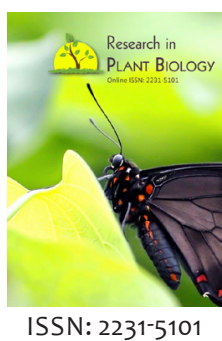

Received: May 12, 2020 Accepted: June 20, 2020 Published: June 29, 2020

*Corresponding Author: Mohammad Anwar Hossain E-mail: anwargpb@bau.edu.bd

\section{Variability for agromorphological traits, genetic parameters, correlation and path coefficient analyses in Lentil (Lens culinaris Medik.)}

\author{
Shahida Akter, Israt Jahan, Md. Amir Hossain, Mohammad Anwar Hossain* \\ Department of Genetics and Plant Breeding, Bangladesh Agricultural University, Mymensingh-2202, Bangladesh
}

\begin{abstract}
Understanding phenotypic and genotypic variability of Bangladeshi lentil (Lens culinaris Medik.) in relation to exotic lentil is important in attempting to widen the genetic base of the germplasm in the country. An experiment was conducted using 30 diverse lentil genotypes to study the agromorphological and genetic variability, heritability, expected genetic advance and inter-relationship of ten yield attributing traits. The genotypes showed highly significant $(p<0.01)$ variations for all of the studied traits. These characters also had higher phenotypic co-efficient of variation (PCV) than those of the corresponding genotypic co-efficient of variation (GCV). High heritability (ranged from 66-98\%) was found among the traits. Seed yield plant ${ }^{-1}$ and number of seeds plant ${ }^{-1}$ showed high heritability accompanied with high genetic advance (as percent mean). Correlation coefficient studies revealed that number of pods plant ${ }^{-1}$, number of seeds plant ${ }^{-1}$ and 100 -seed weight contributed to highly significant $(p<0.01)$ positive correlation with seed yield plant ${ }^{-1}$. Days to $50 \%$ flowering and days to maturity were showed highly significant negative correlation with seed yield plant ${ }^{-1}$. Path analysis showed the highest positive direct effects of 100 -seed weight followed by number of secondary branches plant $^{-1}$ and number of seeds plant ${ }^{-1}$ on seed yield plant ${ }^{-1}$. Days to $50 \%$ flowering via 100 -seed weight contributed the highest negative indirect effect on seed yield plant ${ }^{-1}$. Maximum negative direct effect of plant height and days to $50 \%$ flowering was observed on seed yield plant ${ }^{-1}$. Results indicated that the exotic accessions could be effective for the improvement of the yield of lentil.
\end{abstract}

KEYWORDS: Lentil, Phenotypic and genotypic variability, Correlation, Path coefficient analysis

\section{INTRODUCTION}

Lentil is (Lens culinaris Medik.) also popularly known as Masur which is extensively grown in Bangladesh for its economic importance. It is the second most important pulse crop both in acreage and production but stands first in consumer's preference in Bangladesh [1]. Lentil is considered as poor mean's meat, a substitute of animal protein for the underprivileged people of Bangladesh who cannot afford to buy animal protein $[2,3]$. It is an excellent source of carbohydrates, vitamins, minerals and several essential micro-nutrients like iron, zinc and betacarotene $[4,5,6]$. The crop has great significance in cereal-based cropping systems because it can fix atmospheric nitrogen and thereby enriching the soil by Rhizobium bacteria $[7,8]$. Recently, lentil has received considerable interest by the scientific community due to its higher nutritive value and lower seed yield plant $^{-1}$. Increasing yield is therefore the prime breeding objectives of lentil breeder around the globe including Bangladesh. Low production and acreage of lentil in Bangladesh is due to the shortage of lentil varieties with high yield, poor technological intervention during production and competition for a place in the existing cropping pattern. This lacking can be overcome by developing high yielding varieties with wider adaptability and stability.

Yield is a complex phenotypic trait and depends on many yield attributing traits. Knowledge about genetic parameters of different yield and its contributing characters is essential in formulating an efficient breeding program as it offers a basis for selection with valuable indication needed for hybridizing selected parent materials $[9,10]$. In this case, the biometrical components such as variance, coefficient of variation, standard error and heritability play a significant role for the determination of genetic variability under given population. Estimation of genetic parameters helps to determine the genetic properties present in the population, particularly the degree of uniformity among germplasm [11]. Information on the nature and degree of variation in the local and exotic populations, the extent of

Copyright: (-) The authors. This article is open access and licensed under the terms of the Creative Commons Attribution License (http://creativecommons.org/licenses/by/4.0/) which permits unrestricted, use, distribution and reproduction in any medium, or format for any purpose, even commercially provided the work is properly cited. Attribution - You must give appropriate credit, provide a link to the license, and indicate if changes were made. 
environmental influence on the expression of characters is necessary for fruitful gain in breeding programs $[9,12]$. The genetic parameters also help in the prediction of possible genetic advance through selection based on phenotypic value. Thus selection become difficult unless the breeder aware of the possible genetic architecture of the crop. Hence, the primary requirement of a plant breeder is to have information on association of different characters and their direct and indirect influence on the yield contributing characters. The present investigation was therefore undertaken to generate information on morphological variability within the local and exotic lentil genotypes, and to estimate genetic parameters with correlation and path-coefficient of yield and its attributing components in lentil.

\section{MATERIALS AND METHODS}

\section{Plant Materials}

A total of thirty lentil genotypes were used as plant materials for this study of which twelve local varieties viz., BARI Masur-1, BARI Masur-2, BARI Masur-3, BARI Masur-4, BARI Masur-5, BARI Masur-6, BARI Masur-7, BINA Masur-1, BINA Masur-5, BINA Masur-6, BINA Masur-8, BINA Masur-9 and the rest eighteen genotypes viz., BM-119, BM-120, BM-135, BM-477, BM-502, BM-507, BM-512, BM-680, BM-728, BM-868, BM-908, BM-941, BM-981, BM-1181, BM-1220, BM-1222, BM-1227, BM-1247 were exotic lines collected from International Center for Agricultural Research in the Dry Areas (ICARDA), India.

\section{Experimental Site and Design}

The experiment was carried out during rabi season (November 2015 to March 2016) at the experimental farm of the Department of Genetics and Plant Breeding, Bangladesh Agricultural University, Mymensingh-2202, Bangladesh. The experiment was laid out in a Randomized Complete Block Design with three replicates. Unit plot size was $0.6 \mathrm{~m}^{2}$ with row to row distance $30 \mathrm{~cm}$ and plant to plant distance $5 \mathrm{~cm}$. This experiment was performed under rain-fed conditions however the plot was irrigated once at the flowering stage. Other intercultural operations were done whenever necessary.

\section{Data on Yield and Yield Contributing Components}

Data on ten morphological traits i.e. days to $50 \%$ flowering, days to maturity, plant height $(\mathrm{cm})$, number of primary branches plant $^{-1}$, number of secondary branches plant ${ }^{-1}$, number of pods plant $^{-1}$, number of seeds plant ${ }^{-1}$, number of seeds pod ${ }^{-1}, 100$-seed weight $(\mathrm{g})$ and yield plant $^{-1}(\mathrm{~g})$ were recorded from ten plants which were randomly selected from each replication of each genotype.

\section{Statistical Analysis}

The analysis of variance was performed using appropriate statistical program (MSTATc and PLABSTAT). The genotypic and phenotypic co-efficient of variation were estimated according to the formula presented by Burton [13] and Singh and Chaudhury et al. [14]. Heritability of broad sense $\left(h^{2} b\right)$ was calculated as estimated by Johnson et al. [15] and Hanson et al. [16]. Genetic advance was estimated following the procedure suggested by Johnson et al. [15] and Allard [17]. Genetic advance in percentage of mean was also calculated adopting the formula of Comstock and Robinson [18].

\section{RESULTS}

\section{Phenotypic and Genotypic Co-efficient of Variation, Heritability and Genetic Advance for Yield and Yield Attributing Traits}

The mean square due to genotypes for all the characters under study showed highly significant $(p<0.01)$ variation (Table 1$)$. In the present study, high magnitude of phenotypic variance $\left(\delta^{2} \mathrm{p}\right)$ and genotypic variance $\left(\delta^{2} \mathrm{~g}\right)$ were recorded in number of pods plant $^{-1}$ and number of seeds plant ${ }^{-1}$ whereas low magnitude of $\delta^{2} \mathrm{p}$ and $\delta^{2} g$ were recorded in days to $50 \%$ flowering, days to maturity, plant height, number of primary branches plant ${ }^{-1}$, number of secondary branches plant ${ }^{-1}$, number of seeds pod ${ }^{-1}, 100$-seed weight and yield plant ${ }^{-1}$ (Table 1). Coefficients of variation studies indicated that the values of phenotypic coefficient of variation (PCV) were higher than those of the genotypic coefficient of variation (GCV) for all the traits (Table 1) representing that they all influenced by the environment to some extent in lentil both at the vegetative and reproductive stage. The highest PCV and

Table 1: Estimation of genetic parameters for morphological characters related to yield in 30 lentil genotypes

\begin{tabular}{|c|c|c|c|c|c|c|c|c|}
\hline Parameters/ Traits & Mean square (Genotype) & $\mathrm{PV}\left(\delta^{2} \mathrm{p}\right)$ & $\mathrm{GV}\left(\delta^{2} \mathrm{~g}\right)$ & PCV (\%) & GCV (\%) & $\mathrm{h}^{2} \mathrm{~b}(\%)$ & GA & GA (\%) \\
\hline DFF & $371.091 * *$ & 63.95 & 61.07 & 10.27 & 10.04 & 98.90 & 16.01 & 20.57 \\
\hline DM & $262.465^{* *}$ & 45.52 & 43.11 & 6.01 & 5.85 & 98.72 & 13.44 & 11.97 \\
\hline PH & 214.56 & 33.44 & 28.48 & 12.67 & 11.69 & 85.17 & 10.15 & 22.23 \\
\hline NPB & 0.835 & 0.12 & 0.08 & 10.86 & 8.85 & 66.42 & 0.48 & 14.85 \\
\hline NSB & 15.733 & 2.35 & 1.76 & 10.66 & 9.23 & 74.85 & 2.36 & 16.44 \\
\hline NPP & 1915.86 & 286.89 & 220.75 & 26.54 & 23.28 & 76.95 & 26.85 & 42.08 \\
\hline NSP & 6804.30 & 1035.78 & 835.60 & 30.62 & 27.51 & 80.67 & 53.49 & 50.89 \\
\hline NSPP & 0.153 & 0.029 & 0.024 & 10.38 & 9.41 & 94.49 & 0.31 & 18.85 \\
\hline HSW & 0.254 & 0.045 & 0.033 & 13.26 & 11.35 & 82.73 & 0.34 & 21.27 \\
\hline YPP & 2.677 & 0.411 & 0.337 & 37.05 & 33.53 & 81.90 & 1.08 & 62.51 \\
\hline
\end{tabular}

** indicate significant at $1 \%$ level of probability [Here, DFF=Days to $50 \%$ flowering, DM = Days to maturity, PH=Plant height (cm), NPB=Number of primary branches plant ${ }^{-1}, \mathrm{NSB}=$ Number of secondary branches plant ${ }^{-1}, \mathrm{NPP}=$ Number of pods plant ${ }^{-1}, \mathrm{NSP}=$ Number of seeds plant ${ }^{-1}, \mathrm{NSPP}=\mathrm{Number}$ of seeds pod ${ }^{-1}, \mathrm{HSW}=100$-seed weight $(\mathrm{g}), \mathrm{YPP}=\mathrm{Yield}_{\text {plant }}{ }^{-1}(\mathrm{~g})$.] 
GCV values were observed in case of yield plant ${ }^{-1}(37.05 \%$ and $33.53 \%$ ) followed by number of seeds plant ${ }^{-1}(30.62 \%$ and $27.51 \%)$ and number of pods plant ${ }^{-1}$ (26.54\% and $23.28 \%$ ) while the lowest PCV and GCV value was obtained for days to maturity $(6.01 \%$ and $5.85 \%$ ). Importantly, low difference between GCV and PCV were recorded for days to $50 \%$ flowering, days to maturity, plant height, number of primary branches plant ${ }^{-1}$, number of secondary branches plant ${ }^{-1}$ and number of seeds pod $^{-1}$.

Estimation of heritability in broad sense $\left(h^{2} b\right)$ in this study indicated that all of the characters were highly heritable and the $\mathrm{h}^{2} \mathrm{~b}$ values were 98.9, 98.72, 85.17, 66.42, 74.85, 76.95, 80.67, $94.49,82.73$ and $81.90 \%$ respectively for the traits viz., days to $50 \%$ flowering, days of maturity, plant height, number of primary branches plant ${ }^{-1}$, number of secondary branches plant $^{-1}$, number of pods plant ${ }^{-1}$, number of seeds plant ${ }^{-1}$, number of seeds pod $^{-1}$, 100 -seed weight and yield plant $^{-1}$ (Table 1). The highest GA (\%) was estimated for yield plant ${ }^{-1}(62.51 \%)$ while the lowest value $(11.97 \%)$ was recorded for days to maturity. High heritability with high genetic advance as percent mean was observed for yield plant ${ }^{-1}$ (81.90 and $62.51 \%$, respectively) and number of seeds plant ${ }^{-1}(80.67$ and $50.89 \%$, respectively). On the other hand, high heritability with moderate GA was found for number of pods plant ${ }^{-1}$, plant height, 100-seed weight and days to $50 \%$ flowering (Table 1 ).

\section{Phenotypic and Genotypic Correlation Coefficients Between Yield and Yield Attributing Traits}

The phenotypic and genotypic correlation coefficients among seed yield and its contributing characters are presented in Table 2. Correlation study revealed that genotypic correlation coefficients were always higher than the phenotypic correlation coefficients. In the present study, out of 45 associations, 15 associations were highly significant $(p<0.01)$ at phenotypic level and 17 associations were highly significant $(p<0.01)$ at genotypic level. Both phenotypic and genotypic associations revealed that yield plant ${ }^{-1}$ positively and significantly $(p<0.01)$ correlated with number of pods plant ${ }^{-1}$, number of seeds plant ${ }^{-1}$ and 100-seed weight. Days to $50 \%$ flowering exhibited positive and significant correlation with days to maturity, plant height and number of secondary branches plant ${ }^{-1}$ whereas it showed negative significant correlation with number of pods plant ${ }^{-1}$ and 100-seed weight at both phenotypic and genotypic level. Days to maturity also showed positive significant correlation with plant height but negative significant correlation with number of pods plant ${ }^{-1}$, number of seeds plant $t^{-1}$ and 100 -seed weight both phenotypically and genotypically. Plant height positively and significantly correlated with number of secondary branches plant ${ }^{-1}$ but had negative significant correlation with 100 -seed weight and yield plant ${ }^{-1}$. The number of pods plant ${ }^{-1}$ had positive significant correlation with number of seeds plant ${ }^{-1}$ and 100-seed weight. The number of seeds plant ${ }^{-1}$ was positively and significantly correlated with number of seeds pod $^{-1}$ and 100-seed weight. Yield plant ${ }^{-1}$ had positive but non-significant correlation with number of primary branches plant ${ }^{-1}$ and number of secondary branches plant ${ }^{-1}$ (Table 2).

\section{Phenotypic and Genotypic Path Coefficient Analysis}

Both phenotypic and genotypic path coefficient analysis revealed relationship between grain yield and yield contributing characters which are presented in Table 3. Estimation of direct and indirect effects of both genotypic and phenotypic path coefficients showed that number of secondary branches plant ${ }^{-1}$, number of pods plant ${ }^{-1}$, number of seeds plant ${ }^{-1}$ and 100 -seed weight exhibited high positive direct effects on grain yield plant $^{-1}$. These traits also showed high correlations with grain yield plant ${ }^{-1}$. At phenotypic level, plant height showed negative direct effect on grain yield plant ${ }^{-1}$ with insignificant and negative correlation whereas it showed positive genotypic direct effect on yield plant $t^{-1}$. Days to maturity presented direct negative genotypic effect on grain yield plant $^{-1}$ where the correlation was negatively insignificant. Other characters were remarkable that ultimately resulted positive phenotypic and genotypic direct

Table 2: Coefficients of phenotypic and genotypic correlations among different yield components of 30 lentil genotypes

\begin{tabular}{|c|c|c|c|c|c|c|c|c|c|c|}
\hline Traits & $\mathrm{CC}$ & DM & $\mathrm{PH}$ & NPB & NSB & NPP & NSP & NSPP & HSW & YPP \\
\hline \multirow[t]{2}{*}{ DFF } & $r_{p}$ & $0.641 * *$ & $0.630 * *$ & -0.194 & $0.430 *$ & $-0.407^{*}$ & -0.346 & 0.079 & $-0.574 * *$ & $-0.503 * *$ \\
\hline & $r_{g}$ & $0.653 * *$ & $0.682 * *$ & -0.237 & $0.498 * *$ & $-0.454^{*}$ & $-0.375^{*}$ & 0.079 & $-0.640 * *$ & $-0.550 * *$ \\
\hline \multirow[t]{2}{*}{ DM } & $r_{p}$ & & $0.568 * *$ & 0.110 & 0.186 & $-0.630 * *$ & $-0.554 * *$ & -0.078 & $-0.556 * *$ & $-0.629 * *$ \\
\hline & $r_{g}$ & & $0.610 * *$ & 0.125 & 0.231 & $-0.725^{* *}$ & $-0.622 * *$ & -0.082 & $-0.618 * *$ & $-0.702 * *$ \\
\hline \multirow[t]{2}{*}{$\mathrm{PH}$} & $r_{p}^{9}$ & & & -0.273 & $0.562 * *$ & -0.322 & -0.321 & -0.064 & $-0.367^{*}$ & $-0.424^{*}$ \\
\hline & $r_{g}$ & & & $-0.433 *$ & $0.718 * *$ & -0.325 & -0.331 & -0.076 & $-0.436^{*}$ & $-0.459 *$ \\
\hline \multirow[t]{2}{*}{ NPB } & $r_{p}$ & & & & -0.011 & 0.159 & 0.119 & -0.176 & -0.051 & 0.051 \\
\hline & $r_{g}$ & & & & -0.030 & 0.189 & 0.142 & -0.228 & -0.112 & 0.013 \\
\hline \multirow[t]{2}{*}{ NSB } & $r_{p}$ & & & & & 0.171 & 0.239 & 0.217 & 0.026 & 0.189 \\
\hline & $r_{g}$ & & & & & 0.184 & 0.275 & 0.286 & 0.059 & 0.243 \\
\hline \multirow[t]{2}{*}{ NPP } & $r_{p}$ & & & & & & $0.743 * *$ & 0.111 & $0.496 * *$ & $0.723 * *$ \\
\hline & $r_{g}$ & & & & & & $0.758 * *$ & 0.119 & $0.661 * *$ & $0.754 * *$ \\
\hline \multirow[t]{2}{*}{ NSP } & $r_{p}$ & & & & & & & $0.399 *$ & $0.455^{*}$ & $0.765 * *$ \\
\hline & $r_{g}$ & & & & & & & $0.437 *$ & $0.580 * *$ & $0.793 * *$ \\
\hline \multirow[t]{2}{*}{ NSPP } & $r_{p}$ & & & & & & & & 0.019 & 0.330 \\
\hline & $r_{g}$ & & & & & & & & 0.037 & $0.362 *$ \\
\hline \multirow[t]{2}{*}{ HSW } & $r_{p}$ & & & & & & & & & $0.677 * *$ \\
\hline & $r_{g}$ & & & & & & & & & $0.815^{* *}$ \\
\hline
\end{tabular}

*and ** indicate significant at $5 \%$ and $1 \%$ level of probability respectively, $\left[\right.$ Here, $C$ C $=$ Correlation coefficients, $r_{p=}$ Phenotypic correlation coefficient, $r_{g=}$ Genotypic correlation coefficient] 
Table 3: Partitioning of phenotypic and genotypic correlations into direct and indirect effects of ten important characters related to yield by path analysis in lentil (Diagonally bold figures indicate the direct effect)

\begin{tabular}{|c|c|c|c|c|c|c|c|c|c|c|c|}
\hline Traits & $P C$ & DFF & DM & $\mathrm{PH}$ & NPB & NSB & NPP & NSP & NSPP & HSW & YPP \\
\hline \multirow[t]{2}{*}{ DFF } & $r_{y p}$ & -0.167 & -0.003 & -0.139 & 0.013 & 0.109 & -0.091 & -0.083 & 0.011 & -0.152 & $-0.503 * *$ \\
\hline & $r_{y g}^{y p}$ & 0.013 & -0.305 & 0.023 & -0.056 & 0.101 & 0.045 & -0.009 & 0.024 & -0.387 & $-0.550 * *$ \\
\hline \multirow[t]{2}{*}{ DM } & $r_{y p}^{\text {yg }}$ & -0.107 & -0.005 & -0.126 & -0.007 & 0.047 & -0.140 & -0.133 & -0.011 & -0.147 & $-0.629 * *$ \\
\hline & $r_{y q}$ & 0.008 & -0.466 & 0.021 & 0.029 & 0.047 & 0.072 & -0.015 & -0.024 & -0.374 & $-0.702 * *$ \\
\hline \multirow[t]{2}{*}{$\mathrm{PH}$} & $r_{y p}$ & -0.105 & -0.003 & -0.221 & 0.018 & 0.142 & -0.072 & -0.077 & -0.009 & -0.097 & $-0.424^{*}$ \\
\hline & $r_{y g}^{p p}$ & 0.009 & -0.285 & 0.034 & -0.101 & 0.146 & 0.032 & -0.008 & -0.023 & -0.264 & $-0.459 *$ \\
\hline \multirow[t]{2}{*}{ NPB } & $r_{y p}$ & 0.032 & -0.001 & 0.060 & -0.065 & -0.003 & 0.035 & 0.029 & -0.024 & -0.014 & 0.051 \\
\hline & $r_{y g}$ & -0.0031 & -0.058 & -0.015 & 0.234 & 0.006 & -0.019 & 0.0034 & -0.068 & -0.067 & 0.013 \\
\hline \multirow[t]{2}{*}{ NSB } & $r_{y p}^{\text {yg }}$ & -0.072 & -0.001 & -0.124 & 0.001 & 0.253 & 0.038 & 0.057 & 0.030 & 0.007 & 0.189 \\
\hline & $r_{y g}$ & 0.006 & -0.108 & 0.024 & 0.007 & 0.203 & -0.018 & 0.007 & 0.085 & 0.036 & 0.243 \\
\hline \multirow[t]{2}{*}{ NPP } & $r_{y p}^{y y}$ & 0.068 & 0.003 & 0.071 & -0.010 & 0.043 & 0.223 & 0.178 & 0.015 & 0.131 & $0.723 * *$ \\
\hline & $r_{y g}^{p p}$ & -0.006 & 0.338 & -0.011 & 0.044 & 0.037 & 0.099 & 0.018 & 0.033 & 0.399 & $0.754 * *$ \\
\hline \multirow[t]{2}{*}{ NSP } & $r_{y p}$ & 0.058 & 0.003 & 0.071 & -0.008 & 0.061 & 0.165 & 0.240 & 0.055 & 0.121 & $0.765 * *$ \\
\hline & $r_{y g}$ & -0.005 & 0.290 & -0.011 & 0.033 & 0.056 & -0.075 & 0.024 & 0.131 & 0.351 & $0.793 * *$ \\
\hline \multirow[t]{2}{*}{ NSPP } & $r_{y p}$ & -0.013 & 0.000 & 0.014 & 0.011 & 0.055 & 0.025 & 0.096 & 0.137 & 0.005 & 0.330 \\
\hline & $r_{y g}$ & 0.001 & 0.038 & -0.003 & -0.053 & 0.058 & -0.011 & 0.010 & 0.298 & 0.022 & $0.362^{*}$ \\
\hline \multirow[t]{2}{*}{ HSW } & $r_{y p}$ & 0.096 & 0.003 & 0.081 & 0.003 & 0.007 & 0.110 & 0.109 & 0.003 & 0.265 & $0.677 * *$ \\
\hline & $r_{y g}^{p p}$ & -0.008 & 0.288 & -0.015 & -0.026 & 0.012 & -0.066 & 0.014 & 0.011 & 0.605 & $0.815 * *$ \\
\hline
\end{tabular}

Here, Residual effect for phenotypic path-coefficient $=0.205 \&$ Residual effect for genotypic path-coefficient $=0.098$, [Here,

$\mathrm{PC}=$ Path-coefficients, $r_{\mathrm{yp}}=$ Phenotypic path-coefficient, $r_{\mathrm{yg}}=$ Genotypic path-coefficient $]$

effect to grain yield plant ${ }^{-1}$. The phenotypic residual effect was 0.205 while the genotypic residual effect was 0.098 (Table 3).

\section{DISCUSSION}

\section{Phenotypic and Genotypic Co-Efficient of Variation, Heritability and Genetic Advance for Yield and Yield Attributing Traits}

Thirty lentil genotypes were evaluated for ten morphological traits to evaluate the phenotypic and genotypic variability, genetic parameters and to study the relationship between yield and its components. The mean square due to genotypes under studied traits was highly significant $(p<0.01)$. Highly significant variation that present among the genotypes for its morphological characters indicated the existence of high degree of genetic variation that might be useful for future selection breeding program. In agreement with our results, significant variability in morphological attributes of lentil was also suggested by others $[19,11,20,14,21]$.

Estimation of high heritability along with high genetic advance is an efficient tool for predicting gain under selection rather than heritability alone [22,11]. Similarly, the character showing high heritability will also exhibit high genetic advance [15]. The scrutinized data revealed that the phenotypic variance had been always higher than the genotypic variance for all the traits, thus indicated the influences of the environmental factor on these traits. The highest GCV and PCV was recorded in case of yield plant ${ }^{-1}$, number of seeds plant ${ }^{-1}$ and number of pods plant $^{-1}$ indicated that the variations existed among these traits might allow selection to improve these characters. These results are in agreement with those recorded by previous researchers $[23,24,25,14]$. On the contrary, the lowest value for the PCV and GCV was recorded for days to maturity. In accordance with our results, Edossa et al. [26] and Jeberson et al. [27] also reported the low GCV and PCV for days to maturity in lentil.
Estimated GCV and PCV for days to 50\% flowering, days to maturity, plant height, number of primary branches plant ${ }^{-1}$, number of secondary branches plant ${ }^{-1}$ and number of seeds pod $^{-1}$ showed narrow differences indicating a low influence of the environment on these characters. Similar observation of considerable closeness between GCV and PCV for these characters was also made by others $[28,11,14]$ in lentil. However, as opposed to these findings Ayaz et al. [29], Singh et al. [30] and Jeberson et al. [27] reported higher GCV and PCV for days to $50 \%$ flowering, days to maturity and plant height.

In our experiment, all the traits under study exhibited high broad sense heritability. Hence, these traits might get priority during selection for the improvement of seed yield of lentil. High heritability for most of the studied traits except for plant height and biological yield was reported by others $[31,14]$ in lentil. Bejiga et al. [32] also reported higher heritability for seed weight and days to 50\% flowering. Bicer and Sarker [33] reported higher heritability for days $50 \%$ flowering, days to maturity and 100-seed weight. Importantly, yield plant ${ }^{-1}$ and number of seeds plant ${ }^{-1}$ showed high heritability with high genetic advance, and genetic advance as percent mean. Such high heritability coupled with high genetic advance indicated that these characters were less affected by environmental factors and mainly controlled by additive genes [34] and selection of such traits might be effective for increasing of seed yield. Similar to our results higher heritability and higher genetic advance for the traits yield plant ${ }^{-1}$ and number of seeds plant ${ }^{-1}$ was also suggested by other researchers $[11,14]$ in lentil. Again, high heritability was reported in days to $50 \%$ flowering, days of maturity, number of seeds pod $^{-1}$, plant height, 100-seed weight with moderate genetic advance. High heritability accompanied by moderate to high GCV and genetic gain were also reported for days to $50 \%$ flowering by Anita et al. [35], days of maturity by Nadia et al. [36], number of seeds plant ${ }^{-1}$ by Gangele and Rao [37], number of seeds pod $^{-1}$ 
by Rahul et al. [38], 100-seed weight by Singh and Singh [39] and yield plant ${ }^{-1}$ by Vir et al. [40].

\section{Phenotypic and Genotypic Correlation Coefficients Between Yield and Yield Attributing Traits}

Since grain yield is the ultimate product of lentil, information on its association with other characters contributing towards yield is necessary to identify the best character combination for high yield [41]. These relationships between yield and yield related components are generally studied by the correlation and path coefficient analyses in lentil. Correlation knowledge among different traits and further subdividing of the correlation coefficients into direct and indirect effects on yield is one of the approaches to recognize the nature and extent of the relationship among traits [11]. This nature and magnitude of association between yield and yield attributing traits further helps to select high yielding genotypes in lentil. When more variables are correlated with yield it is important to identify appropriate traits for selection. In such case, path analysis provides an effective means of finding out direct and indirect contribution of different component traits towards seed yield [42]. It could be used for formulation of selection index for effective improvement through selection.

Both phenotypic and genotypic correlation coefficient study showed that yield plant ${ }^{-1}$ was correlated positively with number of primary branches plant ${ }^{-1}$, number of secondary branches plant $^{-1}$, number of pods plant ${ }^{-1}$, number of seeds pod ${ }^{-1}$, number of seeds plant ${ }^{-1}$ and 100-seed weight. Among them, number of pods plant ${ }^{-1}$, number of seeds plant ${ }^{-1}$ and 100 -seed weight suggested that genotypes with high partitioning efficiency gave increase in yield plant ${ }^{-1}$ which was also reported by others $[43,11,44]$. On the contrary, the number of primary and secondary branches plant ${ }^{-1}$ and number of seeds pod ${ }^{-1}$ positively and non-significantly correlated with yield plant $t^{-1}$. The results also found similarity with Amanullah and Hatam [45]. Days to $50 \%$ flowering had positive and highly significant correlation with days to maturity and plant height. Days to $50 \%$ flowering positively and significantly correlated with days to maturity which was also similar with the findings of previous workers [46,47]. Plant height presented positive and significant correlation with number of secondary branches plant $^{-1}$ but negative significant correlation with 100 -seed weight and yield plant ${ }^{-1}$. Number of pods plant ${ }^{-1}$ had positive significant correlation with number of seeds plant $^{-1}$ and 100-seed weight. Number of seeds plant ${ }^{-1}$ was positively and significantly correlated with seeds pod $^{-1}$ and 100 -seed weight. Such observations were also made by Tyagi and Khan [48]. The significant and positive phenotypic and genotypic correlation between characters suggested additive genetic model thereby less affected by the environmental fluctuation. The positive and non-significant association referred information of inherent relation among the pairs of combination. While complex linked relationship between the pairs of combinations were referred by the negative and non-significant association. Therefore, correlation analysis revealed the relationship of the dependent variable yield with its independent variables, thus association of various lentil traits would determine their relative significance to improving yields.

\section{Phenotypic and Genotypic Path Coefficient Analysis}

The relations between grain yield and its contributing characters were studied in detail by path coefficient analysis. This estimation revealed that number of secondary branches plant ${ }^{-1}$, number of pods plant ${ }^{-1}$, number of seeds plant ${ }^{-1}$ and 100 -seed weight had high positive direct effects on grain yield plant ${ }^{-1}$ both at phenotypic and genotypic level. Therefore, improvement of yield in lentil would be possible by the direct selection of these traits. Previous researchers also reported same positive direct effect of yield components on yield $[49,11,19,14]$. These traits also showed high phenotypic and genotypic correlation with grain yield plant ${ }^{-1}$. Such a high correlation with grain yield plant ${ }^{-1}$ was mainly due to the high positive direct effect of 100 -seed weight. In the present study, plant height showed positive direct effect on yield plant ${ }^{-1}$ at genotypic level. In accordance with our results, positive genotypic direct effect of plant height on yield plant ${ }^{-1}$ was also reported in lentil [48] and chickpea [50]. Both phenotypic and genotypic path analysis showed that days to maturity had negative direct effect on yield plant $^{-1}$ where the correlation was negative and insignificant which was also suggested by Tadesse et al. [50]. The phenotypic and genotypic residual effect was 0.205 and 0.098 respectively, indicating that the variation contributed by the nine characters in grain yield plant ${ }^{-1}$ was $79.5 \%$ phenotypically and $90.2 \%$ genotypically (Table 3). Several reasons may be present behind the residual effects towards grain yield in this study such as other causal factors (characters) that not included in the analysis contribute more towards yield and sampling errors. Both correlation and path co-efficient studies showed that number of pods plant ${ }^{-1}$, number of seeds plant ${ }^{-1}$ and 100-seed weight were the most important components for getting higher yield.

\section{CONCLUSION}

It was concluded from this investigation that considerable variation exists among the lentil genotypes for all of the traits that were studied. High magnitude of $\delta^{2} \mathrm{p}$ and $\delta^{2} \mathrm{~g}$ were observed in the traits viz., number of pods plant ${ }^{-1}$ and number of seeds plant ${ }^{-1}$. The highest PCV and GCV values were reported for yield plant ${ }^{-1}$, number of seeds plant ${ }^{-1}$ and number of pods plant ${ }^{-1}$. High heritability, genetic advance and genetic advance as percent mean were recorded for the traits number of seeds plant ${ }^{-1}$ and yield plant ${ }^{-1}$. Results of correlation study revealed that genotypic correlation was always higher than phenotypic ones and both showed that yield plant ${ }^{-1}$ had positive correlation with number of primary branches plant ${ }^{-1}$, number of secondary branches plant ${ }^{-1}$, number of pods plant ${ }^{-1}$, number of seeds pod ${ }^{-1}$, number of seeds plant ${ }^{-1}$ and 100 -seed weight. Both phenotypic and genotypic path coefficient analysis showed highest positive direct effects on grain yield plant $^{-1}$ by the number of secondary branches plant ${ }^{-1}$, number of pods plant ${ }^{-1}$, number of seeds plant ${ }^{-1}$ and 100 -seed weight while negative direct effect on grain yield plant $^{-1}$ was showed by plant height which indicate that these traits might be 
effective for selection for attaining high response in yield improvement in lentil.

\section{ACKNOWLEDGEMENTS}

Authors would like to thank the Ministry of Education, Government of the People's Republic of Bangladesh for providing the research grant to conduct this research. Special thanks to BARI, BINA and ICARDA for providing the seeds.

\section{REFERENCES}

1. Uddin J, Sarker A, Podder R. Development of new 3 lentil varieties in Bangladesh. Proceedings of the 14th Agronomy Conference. Adelaide, South Australia; 2015.

2. Gowda CLL, Kaul AK. Pulses in Bangladesh. BARIFAO Publication; 50-80.

3. Nath UK, Rani S, Paul MR, Alam MN, Horneburg B. Selection of superior lentil (Lens culinaris Medik.) genotypes by assessing character association and genetic diversity. Scientific World Journal. 2014; 63(5): 695-708

4. Grusak MA, Coyne CJ. Variation for seed minerals and protein concentrations in diverse germplasm of lentil [abstract]. North America Pulse Improvement Association Biennial Meeting. 2009; 11.

5. Thavarajah D, Thavarajah P, Sarker A. A global survey of effects of genotype and environment on selenium concentration in lentils: Implications for nutritional fortification strategies. Food Chemistry. 2011: 125: 72-76

6. Ninou E, Papathanasiou F, Vlachostergios DN, Mylonas I, Kargiotido A, Pankou C, Papadopoulos I, Sinapidou E, Tokatlidis I. Intense breeding within lentil landraces for high-yielding pure lines sustained the seed quality characteristics. Agriculture. 2019; 9: 175.

7. Fikiru E, Tesfaye K, Bekele E. Genetic diversity and population structure of Ethiopian lentil landraces as revealed by ISSR marker. African Journal of Biotechnology. 2007; 6(12): 1460-1468.

8. Jaiswal SK, Dhar B. Identification and assessment of symbiotic effectiveness of phage-typed Rhizobium leguminosarum strains on lentil (Lens culinaris Medik) cultivars. Current Microbiology.2011; 62:1503-1509.

9. Datta AK, Hossain MA, Rahman L. Genetic parameters, interrelationship and path-coefficient analysis in soybean. Journal of the Bangladesh Agricultural University. 2005; 3(2): 225-230.

10. Akram S, Hussain BMN, Bari MAA, Burritt DJ, Hossain MA. Genetic variability and association analysis of soybean (Glycine max L. (Merrill) for yield and yield attributing traits. Plant Gene and Trait. 2016; 7(13):1-11.

11. Mekonnen F, Mekbib F, Kumara S, Ahmeda S, Sharman TR. Correlation and path coefficient analysis of seed yield and yield components in lentil (Lens culinaris Medik). African Journal of Plant Science. 2014; 8(11): 507-520.

12. Mekonnen F, Mekbib F, Kumar S, Ahmed S, Sharma TR. Agromorphological traits variability of the Ethiopian lentil and exotic genotypes. Advances in Agriculture. 2014; 15

13. Burton GW. Quantitative Inheritance in Grasses. Proceeding of the 6th International Grassland Congress. 1952; 227-283.

14. Chowdhury MM, Haque MA, Malek MA, Rasel M, Ahamed KU. Genetic variability, correlation and path coeffcient analysis for yield and yield components of selected lentil (Lens culinaris M.) genotypes. Fundamental and Applied Agriculture. 2019; 4(2): 769-776.

15. Johnson HW, Robinson HF, Comstock RE. Estimates of genetic and environmental variability in soybeans. Journal of Agronomy. 1955; 47: 314-318

16. Hanson G, Robinson HF, Comstock. Biometrical studies on yield in segregating population of Korean Lespedeza. Agronomy Journal. 1956; 48: 268-274.

17. Allard RW. Principles of Plant Breeding. John Wiley and Sons USA; 1960.

18. Comstock R, Robinson H. Genetic parameters, their estimate and significance. Proceedings of VI International Grassland Congress. 1952; 1: 284-291.

19. Hussain N, Yaqoob M, Rashid A. Genetic competition among lentil candidate lines for yield and yield components under rain-fed condition. Pakistan Journal of Agricultural Research. 2014; 52(1): 54

20. Singh M, Bisht IS, Kumar S, Dutta M, Bansal KC, Karale M, Sarker A Amri A, Kumar S, Datta SK. Global wild annual Lens collection: A potential resource for lentil genetic base broadening and yield enhancement. PLoS One. 2014; 9: e107781.

21. Sakthivel G, Jeberson S, Singh NB, Sharma PR, Kumar S, Jalaj VK, Sinha B, Singh NO. Genetic variability, correlation and path analysis in lentil germplasm (Lens culinaris Medik.). Journal of Pharmaceutical Innovation. 2019; 8(6): 417-420.

22. Singh RK, Chaudhary BD. Biometrical methods in quantitative genetic analysis. New Delhi, India. Kalyani Publishers; 1985

23. Afiah SAN, Moselhy NMM. Evaluation of selected lentil genotypes under rainfed conditions of Ras El-Hekma, North Western Coast. Annals of Agricultural Science-Ain-Shams University (Egypt). 2001; 46(2): 619-629.

24. Siroshi SPS, Ramashray Y, Ranvir S. Genetic variability, corrections and path analysis of yield and its component characters in lentil (Lens culinaris M.). Plant Archives. 2007; 7(1): 295-299.

25. Dugassa A, Legesse H, Geleta N. Genetic variability, yield and yield associations of lentil (Lens culinaris Medik.) genotypes grown at GitiloNajo, Western Ethiopia. Science, Technology and Arts Research Journal. 2014: 3(4): 10-18.

26. Edossa F, Kassahun T, Endshaw B. A comparative study of morphological and molecular diversity in Ethiopian lentil landrace. African Journal of Plant Science. 2010; 4(7): 241-254.

27. Jeberson MS, Shashidhar KS, Yanar K. Genetic variability, heritability, expected genetic advance and correlation studies of some economical characteristics in lentil. Trends in Biosciences. 2015: 8(5): 1144-1347.

28. Chakrabotry M, Haque MF. Genetic variability and component analysis in lentil (Lens culinaris Medik.). Journal Lentil Research. 2000; 12 199-204

29. Ayaz S, McKenzie BA, Hill GD, McNeil DL. Variability in yield of four grain legume species in a subhumid temperate environment. II. Yield components. The Journal of Agricultural Science. 2004; 142(1): 21-28.

30. Singh G, Singh IS, Kumar R. Genetic variability for seed yield and its component characters in a macrosperma $\times$ microsperma cross of lentil (Lens culinaris Medik.). Crop Improvement. 2004; 31: 206-209.

31. Jain SK, Madaria SK, Rao SK, Nigam PK. Analysis of yield factors in lentil. Indian Journal of Agricultural Research. 1995; 29: 173-180.

32. Bejiga G, Tsegaye S, Tullu A. Stability of seed yield for some varieties of lentil grown in the Ethiopian highlands. Crop Research. 1995; 9: 337-343.

33. Bicer BT, Sakar D. Studies on variability of lentil genotypes in Southeastern Anatolia of Turkey. Notulae Botanicae Horti Agrobotanici Cluj-Napoca. 2008; 36: 20-24.

34. Panse VG, Sukhatme PV. Statistical methods for agricultural workers $2^{\text {nd }}$ Edn. ICAR New Delhi. 1967

35. Anita A, Aich SS, Shrivastava MP. Genetic variability, correlation studies on yield and its components in lentil. Journal of Interacademicia. 2007; 11(3): 247-250.

36. Nadia $Y$, Hanif M, Siddique S. Estimates of genetic parameters and path analysis in lentil (Lens culinaris M.). Pakistan Journal of Agricultural Sciences. 2008; 43(3):44-48

37. Gangele NK, Rao SK. Heritability and genetic advance for yield and its components in lentil. JNKVV Research Journal. 2005; 39(1): 43-46.

38. Rahul S, Pushp S, Brar JS. Genetic studies for physiological traits and their relationship with seed yield in lentil. Journal of Food Legumes. 2007; 20(1): 29-32.

39. Singh IP, Singh JD. Genetics of yield and its components in lentil (Lens culinaris Medic). National Journal of Plant Improvement. 2007; 9(1): 29-31.

40. Vir O, Gupta VP, Vir O. Association among yield and yield contributing characters in microsperma $x$ macropsperma derivatives of lentil. Crop Improvement. 2001; 28: 75-80

41. Gupta R, Begum SN, Islam MM, MS, Alam MS. Characterization of lentil (Lens culinaris M.) germplasm through phenotypic marker. Journal of the Bangladesh Agricultural University. 2012; 10(2): 197204.

42. Abdipur M, Vaezi B, Bavei V, Heidarpur NA. Evaluation of morphophysiological selection indices to improve of drought tolerant lentil genotypes (Lens culinaris Medik) under rainfed condition. American- 
Eurasian Journal of Agricultural \& Environmental Sciences. 2011; 11 : 275-281.

43. Verma AK, Mahto RN, Bhattacharya A. Path analysis in lentil (Lens culinaris Medik). Journal of Research, Birsa Agricultural University. 2004; 16(1): 135.

44. Rahimi MH, Houshmand S, Khodambashi M, Shiran B, Mohammady S. Effect of drought stress on agro-morphological traits of lentil (Lens culinaris Medik.) recombinant inbred lines. Bangladesh Journal of Agricultural Research. 2016; 41(2): 207-219.

45. Amanullah, Hatam M. Grain yield potential of lentils germplasm. Pakistan Journal of Biological Sciences. 2000; 3(10): 1553-1555.

46. Rasheed S, Hanif M, Sadiq S, Abbas G, Asghar MJ, Haq MA. Inheritance of seed yield and related traits in some lentil (Lens culinaris Medik) genotypes. Pakistan Journal of Agricultural Sciences.
2008; 45(3): 49-52.

47. Younis N, Hanif M, Sadiq S, Abbas G, Asghar MJ, Haq MA. Estimates of genetic parameters and path analysis in lentil (Lens culinaris Medik). Pakistan Journal of Agricultural Sciences. 2008; 45(3): 44-48.

48. Tyagi SD, Khan MH. Correlation, path-coefficient and genetic diversity in lentil (Lens culinaris Medik) under rained conditions. International Research Journal of Plant Science. 2011; 2: 191-200.

49. Kakde SS, Sharma RN, Lambade BM, Arial VN. Correlation and path analysis studies in lentil (Lens culinaris M). Annual Review of Plant Physiology. 2006; 20(1): 86-90.

50. Tadesse M, Fikre A, Eshete M, Girma N, Korbu L, Mohamed R, Bekele D, Funga A, Ojiewo CO. Correlation and path coefficient analysis for various quantitative traits in desi chickpea genotypes under rain-fed conditions in Ethiopia. Journal of Agricultural Science. 2016; 8(12): 112-118. 